\title{
Influence of Thermal Modification on Surface Properties and Chemical Composition of Beech Wood (Fagus sylvatica L.)
}

\section{Utjecaj toplinske modifikacije na površinska svojstva i kemijski sastav bukovine (Fagus sylvatica L.)}

\author{
Original scientific paper • Izvorni znanstveni rad \\ Received-prispjelo: 18. 3. 2015. \\ Accepted-prihvaćeno: 29. 1. 2016. \\ UDK: $630 * 813.4 ; 674.031 .632 .22$ \\ doi:10.5552/drind.2016.1520
}

\begin{abstract}
Thermal modification leads to the degradation of the compounds in wood, thereby changing the chemical composition of wood, which can affect the further wood finishing. In order to determine the effect of thermal modification on wood finishing, it is important to know the properties of its surface. In this research, the influence of thermal modification on $\mathrm{pH}$, surface free energy, contact angle of coating and chemical composition of beech wood was studied. The results of this study show that acidity and water contact angle on beech wood was higher and polar component of surface free energy was lower after thermal modification. Furthermore, contact angle of waterborne coating on beech wood was increased by increasing the modification temperature and the content of extractives soluble in hot water and in organic solvent was increased after thermal modification of beech wood.
\end{abstract}

Key words: thermal modification, contact angle, surface free energy, wood chemical composition

SAŽETAK • Toplinska modifikacija uzrokuje razgradnju spojeva u drvu, čime se mijenja kemijski sastav drva što može utjecati na njegovu površinsku obradu. Kako bi se utvrdio učinak toplinske modifikacije na površinsku obradu drva, važno je znati svojstva njegove površine. U ovom je radu istraživan utjecaj toplinske modifikacije na pH drva, njegovu slobodnu površinsku energiju, kvašenje premaza i na kemijski sastav bukovine. Rezultati istraživanja pokazuju da je toplinska modifikacija povećala kiselost drva i kut kvašenja vode na bukovini $i$ smanjila polarne komponente slobodne površinske energije. Nadalje, kut kvašenja vodenog premaza na bukovini povećao se s povećanjem temperature modifikacije, a sadržaj ekstraktiva topljivih u vrućoj vodi $i$ organskom otapalu povećao se nakon toplinske modifikacije bukovine.

Ključne riječi: toplinska modifikacija, kut kvašenja, slobodna površinska energija, kemijski sastav drva

\footnotetext{
Authors are assistant and professor at Faculty of Forestry, University of Zagreb, Zagreb, Croatia.

Autori su asistent i profesorica Šumarskog fakulteta, Sveučilište u Zagrebu, Zagreb, Hrvatska.
} 


\section{INTRODUCTION}

\section{UVOD}

Thermally modified wood, also known as the heat treated wood, has large application outdoors due to reduced hygroscopicity, improved dimensional stability, improved biological durability and attractive appearance, especially for facades, decking and garden furniture. Despite some improved properties compared to unmodified wood, thermally modified wood is still susceptible to surface degradation by weathering when exposed to outdoor conditions. Therefore, it is necessary to protect the surface of the thermally modified wood to prevent discolouration and formation of surface cracks (Militz, 2002; Miklečić et al., 2010). In order to determine the effect of thermal modification on wood finishing, it is important to know the properties of surface of thermally modified wood such as $\mathrm{pH}$ (Ljuljka et al., 1996), wettability (Pétrissans et al., 2003) and surface free energy (De Meijer et al., 2000). In previous research, Bonstra et al. (2007) reported that high temperatures lead to the increase of wood acidity. Moreover, according to research of Gérardin et al. (2007) and Petrič et al. (2012), thermal modification reduces the surface free energy of wood. However, there is no information in literature on the influence of thermal modification on contact angle of waterborne coatings. Furthermore, the change of chemical composition of wood after thermal modification can disrupt the interaction between coating and wood surface. This applies particularly to extractives, which have influence on coating adhesion strength and wettability (Ghofrani et al., 2015).

The aim of this study was to analyse the influence of thermal modification on the surface $\mathrm{pH}$, free energy and contact angle of waterborne coating of beech wood. These characteristics of wood surface could affect the interaction between wood and coating. Furthermore, we wanted to analyse the influence of thermal modification on the change of chemical composition of wood.

\section{MATERIALS AND METHODS 2. MATERIJALI I METODE}

Radial-textured samples of unmodified and thermally modified beech wood (Fagus sylvatica L.) with no visible defects were used in this study. Beech wood is the most widely distributed three species in Croatia and it is often modified to open up new fields of application. The samples had 4-5 annual rings per centimetre, and the width of annual ring was $2-2.5 \mathrm{~mm}$ with $30-48 \%$ share of latewood. All wood samples were conditioned to $8.4 \%$ moisture content at $(23 \pm 2){ }^{\circ} \mathrm{C}$ and $(50 \pm 5) \%$ relative humidity $(\mathrm{RH})$.

Eight wood samples with dimensions of $1020 \mathrm{~mm}$ x $150 \mathrm{~mm} \times 28 \mathrm{~mm}(L \times R \times T)$ have been modified using high temperature and vapour in commercial heat treatment chamber in the industrial process of modification without the use of chemicals. Two temperatures were used for the modification: $190^{\circ} \mathrm{C}$ - lighter samples

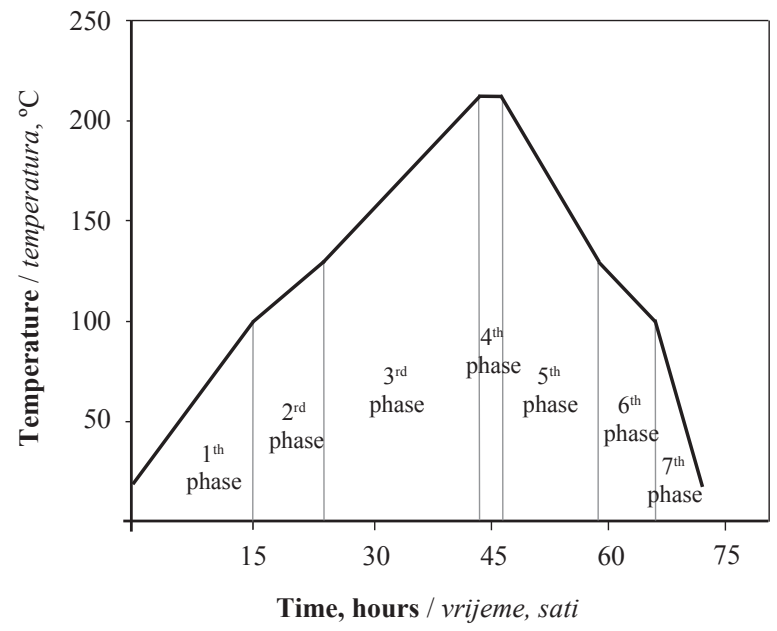

Figure 1 Phases of industrial thermal modification of wood samples

Slika 1. Faze toplinske modifikacije uzoraka drva u industrijskom procesu

(S) and $212{ }^{\circ} \mathrm{C}$ - darker samples (T), as used in ThermooWood process (Finish Thermowood Association). The process of thermal modification lasted 74 hours (Figure 1) and was conducted in seven phases.

\subsection{Determination of wood $\mathrm{pH}$}

2.1. Određivanje $\mathrm{pH}$ drva

For the determination of wood $\mathrm{pH}$, a water extract from the wood was prepared according to the methods of Pedieu et al. (2008). For each type of tested wood, a sample of $25 \mathrm{~g}$ was milled and dried at $(103 \pm 2){ }^{\circ} \mathrm{C}$ to the constant weight, and then conditioned in a desiccator to $(23 \pm 2){ }^{\circ} \mathrm{C}$. Following conditioning, the sample was added into $250 \mathrm{~mL}$ of boiling deionised water and boiled for $20 \mathrm{~min}$ in the Erlenmeyer flask with a reflux condenser. The solution was then filtered and cooled to 23 ${ }^{\circ} \mathrm{C}$. The $\mathrm{pH}$ of the filtered sample was measured with $\mathrm{pH}$ meter Mettler Toledo - SG7. Three measurements were made for each type of wood sample.

\subsection{Determination of wood surface free energy \\ 2.2. Određivanje površinske energije drva}

The surface free energy of unmodified and thermally modified wood samples was calculated from the average contact angles using the Owens Wendt Rabel and Kaelble (OWRK) method (Wu, 1971) and using the Lifshitz-van der Waals - Acide Base (LW-AB) method (Good, 1992). The contact angle used for calculating the surface free energy was measured by the Wilhelmy method. According to that method, a wood sample is immersed in a liquid of known surface tension to a certain depth and the force acting on a vertically immersed plate is measured (Hakkou et al., 2005). In this study, deionised water and formamide as polar liquids and diiodomethane as nonpolar liquid were used (Table 1).

For the determination of surface free energy, four unmodified (N) and thermally modified wood samples were prepared at $190(\mathrm{~S})$ and $212{ }^{\circ} \mathrm{C}(\mathrm{T})$ with dimensions of $100 \mathrm{~mm}$ × $30 \mathrm{~mm}$ × $2 \mathrm{~mm}$. Each sample was then sawn up into three samples with dimensions of 20 
Table 1 The values of surface tension and surface tension components of water, formamide and diiodomethane presented in $\mathrm{mJ} / \mathrm{m}^{2}$

Tablica 1. Vrijednosti površinske napetosti i komponenti površinske napetosti vode, formamida i dijodometana prikazane u $\mathrm{mJ} / \mathrm{m}^{2}$

\begin{tabular}{|c|c|c|c|c|c|c|c|}
\hline \multirow{2}{*}{$\begin{array}{l}\text { Liquid } \\
\text { Tekućina }\end{array}$} & \multirow{2}{*}{$\gamma_{L}$} & \multicolumn{4}{|c|}{ LW-AB method } & \multicolumn{2}{|c|}{ OWRK method } \\
\hline & & $\gamma_{i}^{L W}$ & $\gamma_{i}^{+}$ & $\gamma_{i}^{-}$ & $\gamma_{i}^{A B}$ & $\gamma_{L}^{d}$ & $\gamma_{L}^{P}$ \\
\hline Deionised water / deionizirana voda & 72.8 & 21.8 & 25.5 & 25.5 & 51.0 & 22.0 & 50.2 \\
\hline Formamide / formamid & 58.0 & 39.0 & 2.3 & 39.6 & 19.0 & 32.3 & 26.0 \\
\hline Diiodometane / dijodometan & 50.8 & 50.8 & 0.00 & 0.00 & 0.00 & 50.8 & 0.00 \\
\hline
\end{tabular}

Table 2 Composition of waterborne polyacrylate coating Tablica 2. Sastav vodenoga poliakrilatnog premaza

\begin{tabular}{|l|l|c|}
\hline $\begin{array}{l}\text { Name of component } \\
\text { Naziv sastavnice }\end{array}$ & \multicolumn{1}{|c|}{$\begin{array}{c}\text { Type of component } \\
\text { Vrsta sastavnice }\end{array}$} & $\begin{array}{c}\text { Content, \% } \\
\text { Sadržaj, \% }\end{array}$ \\
\hline Binder / vezivo & $\begin{array}{l}\text { Esters of acrylic and metacrylic acid and styrene } \\
\text { esteri akrilne i metakrilne kiseline } \text { i stiren }\end{array}$ & 70.00 \\
\hline Solvent / otapalo & Deionised water / deionizirana voda & 19.00 \\
\hline Coalescent / koalescent & Isopropyl alcohol, butyl glycol / izopropilni alkohol, glikol butil & 0.80 \\
\hline Rheological additive /reološki aditiv & Nonionic / neionski & 0.40 \\
\hline Defoaming agent /sredstvo protiv pjenjenja & Silicone type / tip silikona & 0.30 \\
\hline Wetting agent /Sredstvo za vlaženje & Silicone type / tip silikona & 0.15 \\
\hline Wax / vosak & $\begin{array}{l}\text { Paraffin and high-density polyethylene } \\
\text { parafin i polietilen velike gustoće }\end{array}$ & 8.20 \\
\hline Other components / ostale sastavnice & No dana / nema podataka & 0.85 \\
\hline
\end{tabular}

mm x $30 \mathrm{~mm} \times 2 \mathrm{~mm}(\mathrm{~L} \times \mathrm{R} \times \mathrm{T})$ and sanded with 80, 120 and 180 grid paper. The cross section of the prepared samples was immersed in nitrocellulose lacquer (2 $\mathrm{mm}$ ) to exclude the absorption of test liquids, and then the samples were conditioned for 24 hours at $(23 \pm 2){ }^{\circ} \mathrm{C}$ and $(50 \pm 5) \% \mathrm{RH}$. The first sample was used to determine the advancing contact angle of deionised water, the second of formamide (99+ \%, J. T. Baker, USA) and the third of diiodomethan (99+ \% Across Organics Belgium). The measurements were carried out at $(23 \pm 2)$ ${ }^{\circ} \mathrm{C}$ and $(50 \pm 5) \% \mathrm{RH}$ with the tensiometer (Krüss $\mathrm{K} 100$ ) by immersing the wood samples in a radial direction with the following parameters: speed before touching the liquid $6 \mathrm{~mm} / \mathrm{min}$, touch sensitivity $0.01 \mathrm{~g}$, immersion velocity $12 \mathrm{~m} / \mathrm{min}$, immersion depth before measuring $2 \mathrm{~mm}$, maximum immersion depth $7 \mathrm{~mm}$.

\subsection{Determination of contact angle of waterborne coating}

2.3. Određivanje kuta kvašenja vodenog premaza

The contact angle was measured by the sessile drop method using a Krüss Drop Shape Analysis System - DSA100. Two unmodified (N) and thermally modified wood samples were prepared at $190(\mathrm{~S})$ and $212{ }^{\circ} \mathrm{C}(\mathrm{T})$ with dimensions of $30 \mathrm{~mm} \times 20 \mathrm{~mm} \times 5 \mathrm{~mm}$ $(L \times R \times T)$. The samples were sanded with 80, 120 and 180 grid paper and conditioned for 72 hours at $(23 \pm 2)$ ${ }^{\circ} \mathrm{C}$ and $(50 \pm 5) \% \mathrm{RH}$ followed by measurement. For each sample, three drops of $5 \mu \mathrm{L}$ of waterborne polyacrylate coating (Table 2) were deposited on the wood sample at different locations.

The value of contact angle was taken after 2 seconds of contact of the coating drop and the wood sample, because the preliminary results showed that this period of time is necessary in order to obtain drop sta- bilisation. The obtained contact angle was the mean value of the left and right contact angle of the drop.

2.4 Determination of wood chemical composition 2.4. Određivanje kemijskog sastava drva

The unmodified and thermally modified samples were milled and sieved to obtain a fraction between 1.19-1.25 mm. The extractives content in the wood samples soluble in organic solvent was determined according to ASTM D1107 with a mixture of ethanolbenzene $(1: 1, \mathrm{v} / \mathrm{v} \%)$, and the extractives content soluble in hot water was determined according to ASTM D1110. The obtained extract was dried in an oven at $(103 \pm 2){ }^{\circ} \mathrm{C}$ to constant weight and the extractives content was determined after isolation and drying to constant mass using the gravimetric method. The lignin content in the wood was determined by Klason method according to TAPPI T222om-11 on the extracted samples with a mixture of ethanol-benzene in which the water content was measured. Similarly as the lignin content, cellulose content was determined on the extracted samples with a mixture of ethanol-benzene in which the water content was measured according to the method of Miranda et al. 2012 (as cited in Kürscher and Hoffer, 1929). The lignin and cellulose content was determined gravimetrically in relation to absolutely dry extracted sample. In determining of extractive, lignin and cellulose content, two measurements were made for each type of wood sample.

\section{RESULTS AND DISCUSION 3. REZULTATI I DISKUSIJA}

The $\mathrm{pH}$ results presented in Table 3 show that thermal modification caused an increase in acidity of 
beech wood. As a reason for the increasing of wood acidity, Bonstra et al. (2007) indicated the formation of formic and acetic acid in the wood when it is subjected to high temperatures. They obtained a slightly higher acidity of thermally modified wood $(\mathrm{pH}=3.5-4)$, but this may be due to the use of different wood species and different parameters during the process of thermal modification. From the obtained results, it can be concluded that there was no significant difference between the lower and higher temperature of modification, suggesting that already at $190{ }^{\circ} \mathrm{C}$ major changes in the $\mathrm{pH}$ of beech wood occurred. An increase in the acidity of thermally modified wood can have a negative effect on curing of coatings and on the interaction of thermally modified wood with metal objects.

The contact angle values of water, formamide and diiodomethane on unmodified and thermally modified wood are presented in Table 4 . The results show that the water contact angle on thermally modified beech wood was higher compared to formamide and diiodomethane. Similar results were obtained for spruce wood (Picea abies Karst.) thermally modified in initial vacuum (Petrič et al., 2012). Furthermore, the increasing of the modification temperature caused increasing of the water contact angle. Hakkou et al. (2005) reported that after heat treatment in the temperature range between 100 and $160^{\circ} \mathrm{C}$, the wood wettability changed suddenly.

Table $3 \mathrm{pH}$ values of unmodified beech wood $(\mathrm{N})$, thermally modified beech wood at $190{ }^{\circ} \mathrm{C}(\mathrm{S})$ and thermally modified beech wood at $212^{\circ} \mathrm{C}(\mathrm{T})$

Tablica 3. $\mathrm{pH}$ vrijednost nemodificirane bukovine $(\mathrm{N})$, bukovine toplinski modificirane na $190{ }^{\circ} \mathrm{C}(\mathrm{S})$ i na $212{ }^{\circ} \mathrm{C}(\mathrm{T})$

\begin{tabular}{|c|c|}
\hline $\begin{array}{c}\text { Type of wood } \\
\text { Vrsta } d r v a\end{array}$ & $\mathrm{pH}$ \\
\hline $\mathrm{N}$ & $4.9(0.00)^{*}$ \\
\hline $\mathrm{S}$ & $4.3(0.01)$ \\
\hline $\mathrm{T}$ & $4.4(0.01)$ \\
\hline
\end{tabular}

* The values in parentheses are standard deviations. / Vrijednosti $u$ zagradama standardne su devijacije.

One of the reasons of higher contact angle of water on the modified wood can be partial degradation of hemicellulose associated with the reorganisation of lignocellulosic compounds in the wood, which is the main cause of hydrophobicity of thermally modified wood (Pétrissans et al., 2003; Hakkou et al., 2005; Gérardin et al., 2007). Furthermore, increasing of the contact angle of water can also cause extractives for which Ayrilmis et al. (2009) found that during the thermal modification migrate towards the wood surface and inactivate it. Extractives on the wood surface can also contaminate the test liquid, which can affect the measurement of the water contact angle with Wilhelmy method (Walinder and Johansson, 2001).

Smaller contact angle of formamide on thermally modified wood compared to unmodified wood was unexpected. It was expected that the ratio of the contact angle of formamide on thermally modified wood as compared to unmodified wood would be similar to the contact angle of water as reported by Gérardin et al. (2007) on beech wood (Fagus sylvatica L.) and pine wood (Pinus sylvestris L.) and Pavlić (2009) on pine wood (Pinus sylvestrys L.), because formamide is a polar liquid like water. One of the reasons for a lower contact angle may be less polarity of formamide compared to water. Petrič et al. (2012) reported that the contact angle of formamide can be affected by increased porosity of thermally modified wood and specific chemical reactions in the wood caused by thermal modification. Swelling of the polysacharide cell wall caused by dimethyl formamide as determined by Inari et al. (2007) may be the cause of low contact angle of formamide compared to the contact angle of water. They also noticed that the chemical modification of wood with phenolic isocyanate in dimethyl formamide had a stronger impact on lignin in thermally modified wood than on lignin in unmodified wood. Table 4 also shows that the contact angle of diiodomethane increased with thermal modification of beech wood and was higher on thermally modified wood at $190^{\circ} \mathrm{C}$ than at $212^{\circ} \mathrm{C}$. In the literature there are various data for the contact angle of diiodomethane on wood, from values of more than $70^{\circ}$ on spruce wood (Picea abies L.) and meranti wood (Shorea spp.) (De Meijer et al., 2000) to values not significantly higher than $0^{\circ}$ on viscoelastic thermal compressed wood (Petrič et al., 2009). From the three test liquids, the smallest dissipation of the contact angle measurements was recorded for the water. A marked increase in the contact angle of water on thermally modified wood will result in poor wetting of aqueous coatings, which may affect the adhesion and properties of coated thermally modified wood during use.

Table 4 Average values of the contact angle $\left(\Theta_{\mathrm{a}}\right)$ on unmodified (N) and thermally modified beech wood at 190 ${ }^{\circ} \mathrm{C}(\mathrm{S})$ and $212{ }^{\circ} \mathrm{C}(\mathrm{T})$

Tablica 4. Srednje vrijednosti kontaktnog kuta $\left(\Theta_{\mathrm{a}}\right)$ na nemodificiranoj bukovini (N) i na bukovini toplinski modificiranoj na $190{ }^{\circ} \mathrm{C}(\mathrm{S})$ i $212{ }^{\circ} \mathrm{C}(\mathrm{T})$

\begin{tabular}{|c|c|c|c|}
\hline \multirow{2}{*}{$\begin{array}{l}\text { Type of } \\
\text { substrate } \\
\text { Tip podloge }\end{array}$} & \multicolumn{3}{|c|}{ Contact angle / kontaktni kut, $\Theta_{\mathrm{a}}\left({ }^{\circ}\right)$} \\
\hline & $\begin{array}{l}\text { Water } \\
\text { Voda }\end{array}$ & $\begin{array}{l}\text { Formamide } \\
\text { Formamid }\end{array}$ & $\begin{array}{l}\text { Diiodomethane } \\
\text { Dijodometan }\end{array}$ \\
\hline $\mathrm{N}$ & $55.9(3.41)^{*}$ & $38.3(6.66)$ & $34.2(9.97)$ \\
\hline $\mathrm{S}$ & 73.0 & $31.1 \quad(6.12)$ & 45.7 (4.60) \\
\hline $\mathrm{T}$ & $81.1 \quad(2.40)$ & $32.4 \quad(5.96)$ & $35.6(5.99)$ \\
\hline
\end{tabular}

* The values in parentheses are standard deviations. / Vrijednosti $u$ zagradama standardne su devijacije.

Results of the surface free energy, dispersing and polar component of the surface free energy of unmodified and thermally modified wood (Table 5) were calculated according to Owens Wendt Rable Kaebi method and to the Lifshitz-van der Waals - Acid Base method. The contact angle results on the wood surface, from which the surface free energy is calculated, depend on a number of variables such as measurement methods, the preparation of the wood surface, measuring time, moisture content, course-grained, early and late wood, surface roughness, surface contamination. With such a large number of influencing variables, comparison of 
the results of the surface free energy from the literature can only provide limited information. According to OWRK method, a reduction of the surface free energy of thermally modified beech wood compared to unmodified wood was obtained with a slight increase of disperse and a high decrease of the polar component with an increase of modification temperature (Table 5). Gérardin et al. (2007) obtained similar results for thermally modified beech (Fagus sylvatica L.) and pine wood (Pinus sylvestris L.) and Petrič et al. (2012) for thermally modified spruce wood (Picea abies Karst.). Results according to LW-AB method also show a reduction of the surface free energy of thermally modified wood compared to unmodified wood. However, only on the samples modified at a higher temperature $\left(212^{\circ} \mathrm{C}\right)$, a strong reduction of the polar component was obtained (Table 5). These results indicate that there is a difference between these two methods of calculating the surface free energy of wood, which should be taken into consideration when they are compared. The resulting reduction of the surface free energy of thermally modified wood is too small to have a greater influence on wetting and adhesion of coatings. However, a marked decrease of the polar component indicates that the polar liquids, such as waterborne coatings, will poorly wet the surface of thermally modified wood, which may result in poorer adhesion.

Figure 2 shows that the wetting of the waterborne coating was better on the surface of the unmodified wood than on the surface of thermally modified wood i.e. it had a higher contact angle on thermally modified wood. The increase of the contact angle of waterborne coating on thermally modified wood was expected because of increasing of the contact angle of water on thermally modified wood (Table 4). Furthermore, the increasing of the coating contact angle on thermally modified wood can be caused by reducing the polar component of the surface free energy (Table 5). It can also be noted that the contact angle of the coating was increased with the increase of the modification temperature, which can be the result of increasing the crystallinity of cellulose (Pétrissans et al., 2003) and increasing the extractive content in thermally modified wood (Figure 3).

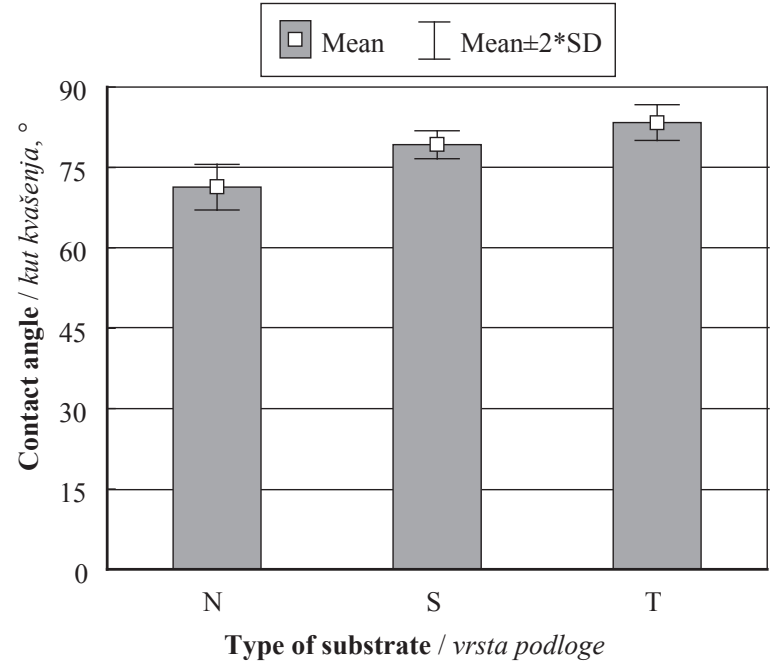

Figure 2 Contact angle of waterborne polyacrylate coating on unmodified $(\mathrm{N})$ and thermally modified beech wood at $190{ }^{\circ} \mathrm{C}(\mathrm{S})$ and $212{ }^{\circ} \mathrm{C}(\mathrm{T})$

Slika 2. Kut kvašenja vodenoga poliakrilatnog premaza na nemodificiranoj bukovini $(\mathrm{N})$ i na bukovini toplinski modificiranoj na $190{ }^{\circ} \mathrm{C}(\mathrm{S})$ i $212^{\circ} \mathrm{C}(\mathrm{T})$

Figure 3 presents the content of extractives (soluble in hot water and organic solvent), cellulose and lignin before and after thermal modification of beech wood. It can be seen that the content of extractives soluble in hot water was increased after modification regardless of the modification temperature, while the content of extractives soluble in organic solvent and lignin was increased with the increase of the modification temperature. Similar results were obtained for thermally modified Norway spruce (Picea abies L.), Scots pine (Pinus sylvestris L.) and Radiata pine (Pinus radiate D.) (Boonstra and Tjeerdsma, 2006) and for Turkey oak (Quercus cerris L.) (Todaro et al., 2013). According to the research of Esteves and Pareira (2009), most extractives disappear or decompose during thermal modification; however, new compounds are formed, which are isolated as a result of degradation of the compounds in the cell walls of the wood. Boonstra and Tjeerdsma (2006) noted that increasing of the extractives content also attributed to the degradation of the cell walls of the

Table 5 Surface free energy of unmodified (N) and thermally modified beech wood at $190{ }^{\circ} \mathrm{C}(\mathrm{S})$ and $212{ }^{\circ} \mathrm{C}(\mathrm{T})$ obtained by OWRK method

Tablica 5. Slobodna površinska energija nemodificirane bukovine (N) i bukovine toplinski modificirane na $190{ }^{\circ} \mathrm{C}(\mathrm{S})$ i 212 ${ }^{\circ} \mathrm{C}(\mathrm{T})$ dobivene OWRK metodom

\begin{tabular}{|c|c|c|c|c|c|c|c|c|}
\hline \multirow{2}{*}{$\begin{array}{c}\text { Type of } \\
\text { substrate }\end{array}$} & \multicolumn{6}{|c|}{ Surface free energy / Slobodna površinska energija, $\mathrm{mJ} / \mathrm{m}^{2}$} \\
\cline { 2 - 9 } Tip podloge & \multicolumn{3}{|c|}{ OWRK method } & \multicolumn{5}{|c|}{ LW-AB method } \\
\cline { 2 - 9 } & $S_{\text {spolar }}$ & $S_{\text {sdispers }}$ & $s_{\text {stotal }}$ & $\gamma_{\mathrm{SV}}{ }^{\mathrm{LW}}$ & $\gamma_{\mathrm{SV}}{ }^{+}$ & $\gamma_{\mathrm{SV}}{ }^{-}$ & $\gamma_{\mathrm{SV}}{ }^{\mathrm{AB}}$ & $\gamma_{\text {tot }}$ \\
\hline $\mathrm{N}$ & 13.9 & 38.7 & 52.6 & 42.4 & 20.9 & 0.4 & 6.1 & 48.5 \\
\hline $\mathrm{S}$ & 6.8 & 39.9 & 46.7 & 36.7 & 2.4 & 4.7 & 6.8 & 43.4 \\
\hline $\mathrm{T}$ & 2.6 & 46.3 & 48.9 & 41.8 & 0.1 & 4.0 & 1.4 & 43.2 \\
\hline
\end{tabular}

$s_{\text {spolar }}$ - polar component / polarna komponenta

$S_{\text {sdispers }}$ - dispersion component / disperzijska komponenta

$s_{\text {stotal }}$ - total surface free energy / ukupna slobodna površinska energija

$\gamma_{\mathrm{SV}}^{\mathrm{LW}}$ - Lifshitz-van der Waals component / Lifshitz-van der Waalsova komponenta

$\gamma_{\mathrm{SV}}^{+}$- Lewis acid parameter / Lewisov kiselinski parametar

$\gamma_{\mathrm{SV}}{ }^{-}$- Lewis base parameter / Lewisov bazni parametar

$\gamma_{\mathrm{SV}}{ }_{\mathrm{AB}}$ - Lewis acid-base component / Lewisova kiselinsko-bazna komponenta

$\gamma_{\text {tot }}$ - total surface free energy / ukupna slobodna površinska energija 


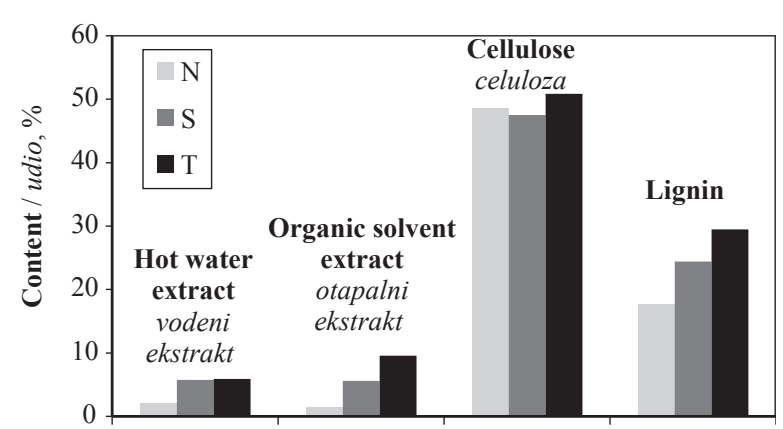

Figure 3 Percent content of extractives, cellulose and lignin in unmodified $(\mathrm{N})$ and thermally modified beech wood at $190{ }^{\circ} \mathrm{C}(\mathrm{S})$ and $212^{\circ} \mathrm{C}(\mathrm{T})$

Slika 3. Postotni udio ekstraktivnih tvari, celuloze i lignina u nemodificiranoj bukovini (N) i u bukovini toplinski modificiranoj na $190{ }^{\circ} \mathrm{C}(\mathrm{S})$ i $212^{\circ} \mathrm{C}(\mathrm{T})$

wood. Therefore, it can be assumed that increasing of extractives content after thermal modification of beech wood indicates a greater degradation of the wood. Kamdem et al. (2002) suggested that higher lignin content does not mean the creation of new lignin during thermal modification than a reduction of other compounds in the wood. Furthermore, higher lignin content after thermal modification can be explained by the formation of some compounds by the thermal decomposition of carbohydrate, which can be contained in the isolated lignin (Yildiz et al., 2006). The content of cellulose was slightly changed after thermal modification of beech wood, indicating that the cellulose is stable at high temperatures up to $212^{\circ} \mathrm{C}$.

\section{CONCLUSION}

\section{ZAKLJUČAK}

In this research, it was found that thermal modification caused higher acidity of beech wood, while there were no significant differences in wood $\mathrm{pH}$ between modification temperature at $190^{\circ} \mathrm{C}$ and $212^{\circ} \mathrm{C}$.

Furthermore, thermal modification caused higher contact angle of water and lower polar component of wood surface free energy, which led to poor wetting of the thermally modified beech wood with waterborne coating.

The results showed that there is a difference between OWRK and LW-AB methods of calculation of wood surface free energy.

The contact angle of waterborne coating was increased on thermally modified beech wood with the increase of the modification temperature.

The content of extractives soluble in hot water and in organic solvent was higher after thermal modification. However, the content of extractives soluble in organic solvent increased with the increase of the modification temperature, which can be an indicator of wood degradation at high temperatures.

Klason method of lignin isolation proved not suitable for lignin isolation from thermally modified wood because with this method wood compounds formed by the thermal decomposition can be isolated.

\section{REFERENCES}

\section{LITERATURA}

1. Ayrilmis, N.; Dundar, T.; Candan, Z.; Akbulut, T. 2009: Wettability of fire retardant treated laminated veneer lumber (LVL) manufactured from veneers dried at different temperatures. BioResources, 4: 1536-1544.

2. Boonstra, M. J.; Tjeerdsma, B. 2006: Chemical analysis of heat treated softwoods. Holz als Roh- und Werkstoff. 64(3):204-211 http://dx.doi.org/10.1007/s00107-005-0078-4

3. Boonstra, M. J.; van Acker, J.; Kegel, E.; Stevens, M. 2007: Optimisation of a two-stage heat treatment process: durability aspects. Wood Science and Technology, 41(1):31-57 http://dx.doi.org/10.1007/s00226-006-0087-4.

4. De Meijer, M.; Haemers, S.; Cobben, W.; Militz, H. 2000: Surface energy determinations of wood: Comparison of methods and wood species. Langmuir, 16(24):9352-9359 http://dx.doi.org/10.1021/la001080n.

5. Estevez, B. M.; Pereira, H. M. 2009: Wood modification by heat treatment: a review. BioResources, 4(1):370-404.

6. Gérardin, P.; Petrič, M.; Pétrissans, M.; Lambert, J.; Ehrhrardt, J.J. 2007: Evolution of wood surface free energy after heat treatment. Polymer Degradation and Stability. 92:653-657 http://dx.doi.org/10.1016/j.polymdegradstab.2007.01.016.

7. Gofrani, M.; Mirkhandouzi, F. Z.; Ashori, A. 2015: Effects of extractives removal on the performance of clear varnish coatings on boards. Journal of Composite Materials. November, 3, 2015

http://dx.doi.org/10.1177/0021998315615205.

8. Good, R. J. 1992: Contact angle, wetting, and adhesion: a critical review. Journal of Adhesion Science and Technology, 6(12):1269-1302 http://dx.doi.org/10.1163/156856192x00629.

9. Hakkou, M.; Pétrissans, M.; El Bakali, I.; Gérardin, P.; Zoulalian, A. 2005: Wettability changes and mass loss during heat treatment of wood. Holzforschung, 59:35-37 http://dx.doi.org/10.1515/hf.2005.006.

10. Inari, G.N.; Petrissans, M.; Gerardin, P. 2007: Chemical reactivity of heat-treated wood. Wood Science and Technology, 41(2):157-168 http://dx.doi.org/10.1007/s00226-006-0092-7.

11. Kamdem, D. P.; Pizzi, A.; Jermannaud, A. 2002: Durability of heat-treated wood. Holz als Roh- und Werkstoff, 60(1):1-6 http://dx.doi.org/10.1007/s00107-001-0261-1.

12. Ljuljka, B.; Sertić, V.; Grbac, I.; Jirouš-Rajković, V. 1996: Investigation into the changes of wood surface layer by measurement of $\mathrm{pH}-$-value. Drvna industrija, 47(3):101-107.

13. Miklečić, J.; Jirouš-Rajković, V.; Pervan, S.; Grujić, Saša. 2010: Oils usage in finishing of thermally modified wood in outdoor applications. In: Proceedings of the 21 th International scientific conference Wood is good - Transfer of knowledge in practice as a way out of the crisis. R. Despot, ed. 15 October, Zagreb, Croatia.

14. Militz, H. 2002: Heat Treatment Technologies in Europe: Scientific Background and Technological State-of-Art In: Proceedings of the Conference on "Enhancing the durability of lumber and engineered wood products" February 11-13, 2002, Kissimmee, Orlando. Forest Products Society, Madison, US.

15. Miranda, I.; Gominho, J.; Pereira, H. 2012: Incorporation of bark and tops in Eucalyptus Globulus wood pulping. Bioresources, 7(3):4350-4361.

16. Pavlič, M. 2009: Lastnosti površinskih premazov v odvisnosti od njihovih interakciji $\mathrm{s}$ termično modi- 
ficiranim lesom. Doctoral thesis, Biotehniška fakultetaUniverza v Ljubljani, Oddelek za lesarstvo.

17. Pedieu, R.; Riedl, B.; Pichette, A. 2008: Measurement of wood and bark particles acidity and their impact on the curing of urea formaldehyde resin during the hot pressing of mixed panels. Holz als Roh- und Werkstoff, 66(2):113$117 \mathrm{http}: / / \mathrm{dx}$.doi.org/10.1007/s00107-007-0212-6.

18. Petrič. M.; Kutnar, A.; Kričej, B.; Pavlič, M.; Kamke, F. A.; Šernek, M. 2009: Surface free energy of viscoelastic thermal compressed wood. In: Contact Angl, Wettability and Adhesion. K. L. Mittal ed. Brill Academic Pub, Leide, The Netherlands

http://dx.doi.org/10.1163/ej.9789004169326.i-400.131.

19. Petrič, M.; Kričej, B.; Pavlič, M.; Kutnar, A. 2012: Surface properties of wood thermally modified in vacuum at $210^{\circ} \mathrm{C}$. In: Proceedings of the 6th European Conference on Wood Modification. D. Jones, H. Militz, M. Petrič, F. Pohleven, M. Humar and M. Pavlič eds. 17-18 September, Ljubljana, Slovenia.

20. Pétrissans, M.; Gérardin, P.; El Bakali, I.; Serraj, M. 2003: Wettability of heat-treated wood. Holzforschung, 57:301-307 http://dx.doi.org/10.1515/hf.2003.045

21. Todaro, L.; Dichicco, P.; Moretti, N.; D`Auria, M. 2013: Effect of combined steam and heat treatments on extractives and lignin in sapwood and heartwood of turkey oak (Quercus cerris L.) wood. BioResources, 8(2):1718-1730 http://dx.doi.org/10.15376/biores.8.2.1718-1730.

22. Walinder, M. E. P.; Johansson, I. 2001: Measurement of wood wetability by Wilhelmy method. Part 1 . Holzforschung, 55:21-32

http://dx.doi.org/10.1515/hf.2001.005.
23. Wu, S. 1971: Calculation of interfacial tension in polymer systems. Journal of Polymer Science Part C: Polymer Symposiy, 34(1):19-30 http://dx.doi.org/10.1002/polc.5070340105.

24. Yildiz, S.; Gezer, E. D.; Yildiz, U. C. 2006: Mechanical and chemical behaviour of spruce wood modified by heat. Bulding and Environment, 41(12): 1762-1766 http://dx.doi.org/10.1016/j.buildenv.2005.07.017.

25. *** ASTM D1107 (2007): Standard Test Method for Ethanol-Toluene Solubility of Wood.

26. *** ASTM D1110 (2007): Standard Test Methods for Water Solubility of Wood.

27. *** TAPPI T 222 om-11 (2011): Acid-insoluble lignin in wood and pulp.

28. *** 2003: "ThermoWood Handbook" (online), International ThermoWood Association, https://asiakas.kotisivukone.com/files/en.thermowood.kotisivukone.com/tiedostot/tw_handbook_080813.pdf. (Accessed Nov. 17, 2015).

\section{Corresponding address:}

JOSIP MIKLEČIĆ, Ph.D.

University of Zagreb

Faculty of Forestry

Department of Furniture and Wood Products

Svetosimunska 25

10000 Zagreb, CROATIA

e-mail: jmiklecic@sumfak.hr 